\title{
ECOLOGICAL RISKS IN AGRICULTURE: PROBLEM-ORIENTED APPROACH
}

\author{
Oleg Zakharchenko \\ Odessa State Academy of Civil Engineering and Architecture \\ 4 Didrikhsona str., Odessa, Ukraine, 65029 \\ robin_a@ukr.net
}

\begin{abstract}
Intensification of agricultural production processes is accompanied by an increase not only in the productivity of agricultural crops and the productivity of animals, but also in the negative impact on the environment. Many agricultural producers do not adhere to scientifically grounded crop rotations, norms for introducing mineral fertilizers and doses of pesticides, rules for keeping and feeding animals, storing and recycling animal waste, etc., which leads to contamination of surface and groundwater, soil, air. To take into account the negative impact on the environment, it is advisable to use the form developed by us to assess the level of environmental risk and damage in agriculture.
\end{abstract}

Keywords: natural environment, agricultural sector, crop production, cattle breeding, environmental risks, environmental damage.

\section{Introduction}

The role of agriculture as an industry for the production of food for the population and raw materials for the industry is difficult to overestimate. The share of agricultural land in the total area of world land is about $38.5 \%$. The total volume of the world water intake used for agriculture is $95 \%$. In the field of agricultural production, according to various estimates, employs about 1 billion of the world's population. Also note that one workplace in agriculture creates from five to seven jobs in industry and other sectors of the economy.

The agricultural sector, from one side - a set of organized business entities associated with the use of the main tools and objects of labor - agricultural land - for own use and sale in the market, on the other - the results of entities directly or indirectly, positively or negatively affect the environment.

In agriculture, in addition to greenhouse gases, are frequent pollution of soil and water sources (rivers, lakes, ponds, reservoirs, groundwater) by mineral fertilizers and pesticides. These problems, in their turn, are directly or indirectly related to the causes of local environmental disasters (especially at the village level). The combination of the foregoing demonstrates the need for further study of environmental risk from the standpoint of problem-oriented approach.

\section{Analysis of the literature data and statement of the problem}

During the work we used results of individual scientists of the research topic, data of the European Environment and Agriculture, the Global Forum reports FAO/WHO, staff authorities to ensure food security, statistical information, online resources.

Thus, scientists [1] examine modern agricultural technology management and economic and environmental risks from the perspective of an integrated approach, revealing both theoretical problems and practical side of the issue and the methods and ways to reduce the environmental and economic risks.

Attention is paid to practical analysis of the impact of agriculture on the environment. Also in the work are disclosed factors and directions of environmental policy implementation in agriculture today [2].

Some authors detailing agricultural risks and ways to reduce them. However, their work focuses on economic issues of agricultural risks and environmental risks as a part of agricultural risks are not considered $[3,4]$. 
The specificity of the threat of global ecological collapse is also environmental pollution, which has become as the global problem in the XX century. This created a new state-society relationship with the natural environment, which most significant property is the interweaving and mutually reinforcing effect of environmental problems. Thus, a sharp decrease of water resources is the result of intensive extraction over natural growth and pollution. Another example. Burning huge quantities of fuel, cutting out forests, contamination of ocean with oil products and pesticides (which leads to the death of vegetation in it - the main supplier of oxygen in the atmosphere) - all of which taken together reduce the amount of oxygen in the atmosphere [5].

By some estimates, during the existence of human civilization has been broken for about $70 \%$ of biological systems able to process negative products of human activity. Scientists estimate in 40 years possible occurrence of so-called irreversible process, when the share of pollution exceeds the environment to neutralize harmful emissions and global environmental disaster will come [6].

In the structure of FAO [7] operates a department of natural resources management and environmental protection, which includes sections on environmental issues, climate change and bioenergy, conservation and use of land and water resources.

As for statistical information, FAO presents FAOSTAT data on the emission rate in agriculture [8]. They contain information about the amount of greenhouse gases released per unit of agricultural products on farms in the production of meat, milk, eggs, rice and other crops.

So the problematic question, connected with environmental risks is not only national but international in nature.

\section{Aims and tasks of research}

The purpose of this work is to study environmental risks in the agricultural sector comprehensively. To achieve the goal, the following tasks were set:

- open understanding of environmental risks in agriculture;

- to classify environmental risks and problems accompanying them;

- develop a table of environmental risks and damage in agriculture.

\section{Materials and methods of research}

The environmental risk refers to the probability of the adverse environmental effects of any changes of natural objects and factors [9]. We believe that environmental risks in agriculture is the probability of negative impact on the environment of industrial and technological factors and inaction of business entities. Industrial and technological factors include the technology of production (cultivation) of products, a set of agricultural machinery needed for production processes, etc. Inactivity of business entities is manifested in a situation in which managers have knowingly assumed the occurrence of negative impact factors, and have not taken preventive measures or measures to eliminate the consequences of the problem.

Environmental risks are a part of environmental policy at different levels of management hierarchy (micro, meso, macro, international (global) level). In Ukraine, the issues of ecology are regulated by the Law of Ukraine "On Environmental Protection" [10]. This law determines the legal, economic and social bases for the organization of environmental protection in the interests of present and future generations. Thus, the operating business entities in the agricultural sector are obliged to adhere to the norms of the law. Environmental standards set maximum permissible emissions and discharges of polluting chemicals to the environment, levels of permissible adverse effects of them on physical and biological factors [10].

In the process of research, the following methods were used: analysis and synthesis (impact of agrarians' activity on the environment); qualitative methods for assessing environmental risks (involves identifying sources and causes of risk of processes and works, identifying zones and types of risk, identifying the practical benefits and possible negative consequences that may arise in the process of implementing processes that involve risk); quantitative methods for assessing environmental risks (obtaining a numerical expression of individual risks with the definition of the characteristic of probability and possible losses). 


\section{Results}

Environmental risks in agriculture, in our opinion, may be classified as follows:

1) dependent from business entities (internal) - subjective nature;

2) independent from business entities (external) - objective nature.

A characteristic feature of risks subjective nature is the ability to neutralize the occurrence of environmental problems to a minimum. These primarily include: in crop - entering in pesticides (chemicals) and fertilizers excess; in livestock - wastes of animals and birds.

In 1975 they pointed to ecological problems in agriculture. Selective destruction or significant reduction in the number of renewable natural resources violates subtle and confusing communication in ecosystems, leading to their depletion and degradation, violation of ecological balance. Created by the same person, artificial biogeocoenoses are not as stable as natural ones. To increase their resistance to "pests" of agriculture one has to use chemical pesticides. However, "the widespread use of pesticides and other chemicals in agriculture, in some cases leads to serious environmental consequences: death of insects (especially bees) and birds, a threat to fauna of rivers, lakes and marine waters. The chemicals content in feed for livestock, as well as in food, leads to their accumulation in the human body more and more" [11].

The main resource in the agricultural sector is land. As a result unreasoned economic policies of agricultural land use, reduced their fertility, occurs soil compaction, waterlogging, soil erosion, etc.

As a result of human activity, changing landscape of entire continents, such agrolandscape completely changed the North China Plain, where once grew subtropical forest, moving to the north in the Ussuri taiga, and to the south in the jungles of Indochina. In Europe agrolandscape replaced deciduous forests, arable land in Ukraine has replaced the steppe.

Agricultural landscapes were unstable, leading to a number of local and regional environmental disasters. Thus, improper land reclamation has caused salinization and the loss of most of the arable land of Mesopotamia, a large level of tillage caused dust storms in Kazakhstan and the US, livestock grazing and agriculture has led to desertification in the area Saharan Africa [12].

At the beginning of construction of irrigation salinity in the US brought down huge areas of agricultural land, which desalinity required large additional costs [13].

"Agriculture is perhaps doubled the intensity of erosion - said an American scientist Gordon Walmen and adds: - But it is necessary to consider which area of the country concerned". For 1977 US lost from arable land about 3 billion tons of soil. And about two-thirds of this amount was washed with water, otherwise scattered by the wind [13].

Similar problems are observed in the former CIS. Today $19 \%$ of Belarus is erosion-hazardous. If we talk specifically on agricultural land then $45 \%$ of arable land is erosion-hazardous, while $10 \%$ is exposed to erosion now. Before it caused environmentally unwarranted drainage of wetlands, and the use of the land for agricultural purposes, and land degradation due to intensive use of fertilizers and pesticides. Peat is particularly vulnerable among the drained land; humus layer is lost by wind and turned into unsuitable for agriculture. This process is constantly evolving - until 2020 such peat will be by $10 \%$ more. An additional factor in the destruction of soil layer was the seal of land as a result of handling heavy machinery [14].

The average annual loss of humus in typical black soil of Ukraine ranges from 0.3 to $1.2 \mathrm{t} / \mathrm{ha}$. Measurement results of humus content in agro-station "Customs" (Kyiv region) have shown that over 54 years of plowing humus content decreased from $9.12 \%$ to $5.6 \%$ [15].

With the present level of agricultural chemicalisation of production and significantly increasing number and expanding range of pesticides, environmental pollution is critical and requires the installation of strict regulations and well organized system for monitoring their compliance. The causes of environmental pollution by pesticides are violating rules of their application, the use of persistent preparations and other technological factors (Fig. 1) [16].

Persistence (duration of effect on the environment) of pesticides may be more than 18 months (I group), 18 months (II group), 12 months (III group), 6 months (IV group), 3 months (V group) and at least 3 months (VI group) [17]. 


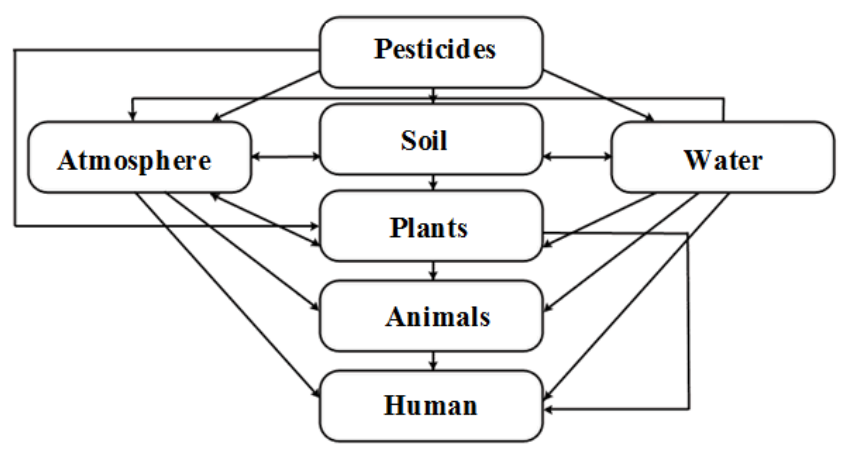

Fig. 1. Circulation scheme of pesticides in the environment

The use of pesticides led to pests' emergence and to pathogenic flora resistant to them. In response, the use of more and heavy pesticides in large quantities even stronger destroys the environment and eventually still leads to a resistance to these preparations [14].

Thus, the negative effects of chemicals on the environment and the population are the important element of improving environmental safety.

Mineral fertilizers provide a significant boost crop. At the same time, the depletion of land in humus, the lack of evidence-based rotation leads to excessive mineral fertilizers, especially nitrogen. The implications of this economic policy lead to terrible consequences - the accumulation of nitrates in food crop production that pass through meat and milk, and eventually enter the body.

The combined effect of residual traces of pesticides and nitrates, primarily in vegetables, especially greenhouse, has a devastating effect on the development of the human body and not only leads to poisoning, but also to fatal consequences.

Researchers of USA, Germany, Czech Republic, Slovakia, Russia, Ukraine found that nitrites and nitrates cause methemoglobinemia in humans, cancer of stomach, adversely affecting the nervous and cardiovascular systems, the development of embryos [18].

The paradox of the environmental situation in agriculture is that the industry based on the use of environmentally safe and practically inexhaustible energy of the sun (about $95 \%$ of solids plants - is accumulated solar energy), was among the biosphere dangerous and emissions of CO in the atmosphere today are by $10 \%$ ahead of industry and transportation that burn fossil fuels [15].

The same data are supported by FAO statistical studies on methane emissions (Fig. 1) [19]. After carbon dioxide $\left(\mathrm{CO}_{2}\right)$, methane $\left(\mathrm{CH}_{4}\right)$ is the second most important well-mixed greenhouse gas contributing to human-induced climate change. In a time-horizon of 100 years, $\mathrm{CH}_{4}$ has a Global Warming Potential (GWP-100) 28 times larger than $\mathrm{CO}_{2}$. The level of $\mathrm{CH}_{4}$ in the atmosphere is over $150 \%$ higher than in pre-industrial times, and it is responsible for $20 \%$ of the global warming produced by all well-mixed greenhouse gases. Methane is transformed into water vapor in the stratosphere. Methane also produces ozone in the troposphere, which is a pollutant with negative impacts on human health and ecosystems. The atmospheric life time of methane is $10 \pm 2$ years [20].

For the decade of 2003-2012, global emissions of methane are 558 (540-568) $\mathrm{Tg} \mathrm{CH}_{4}$ per year as estimated from atmospheric inversions (top-down approach). The global $\mathrm{CH}_{4}$ sink is $548 \mathrm{Tg} \mathrm{CH}_{4}$ per year. The source-sink mismatch reflects, and is consistent with, the observed average imbalance in the atmosphere of $10 \mathrm{Tg} \mathrm{CH}_{4}$ per year (the $\mathrm{CH}_{4}$ growth rate). The sum of all sources as estimated from inventories and modeling (bottom-up approaches) is 736 (596-884) $\mathrm{Tg} \mathrm{CH}_{4}$, $34 \%$ higher than estimated from the top-down approach and reflecting the compounded uncertainties of the multiple $\mathrm{CH}_{4}$ sources [21].

Common disorders that cause agricultural activities include [12]:

- contamination of surface waters (rivers, lakes, seas) and degradation of aquatic ecosystems with eutrophication;

- groundwater contamination;

- deforestation and degradation of forest ecosystems (deforestation); 
- violation of water treatment over large areas (with drainage or irrigation);

- desertification as a result of breach of complex structures, soils and vegetation;

- destruction of natural habitats of many species of living organisms and the consequent extinction and disappearance of rare species.

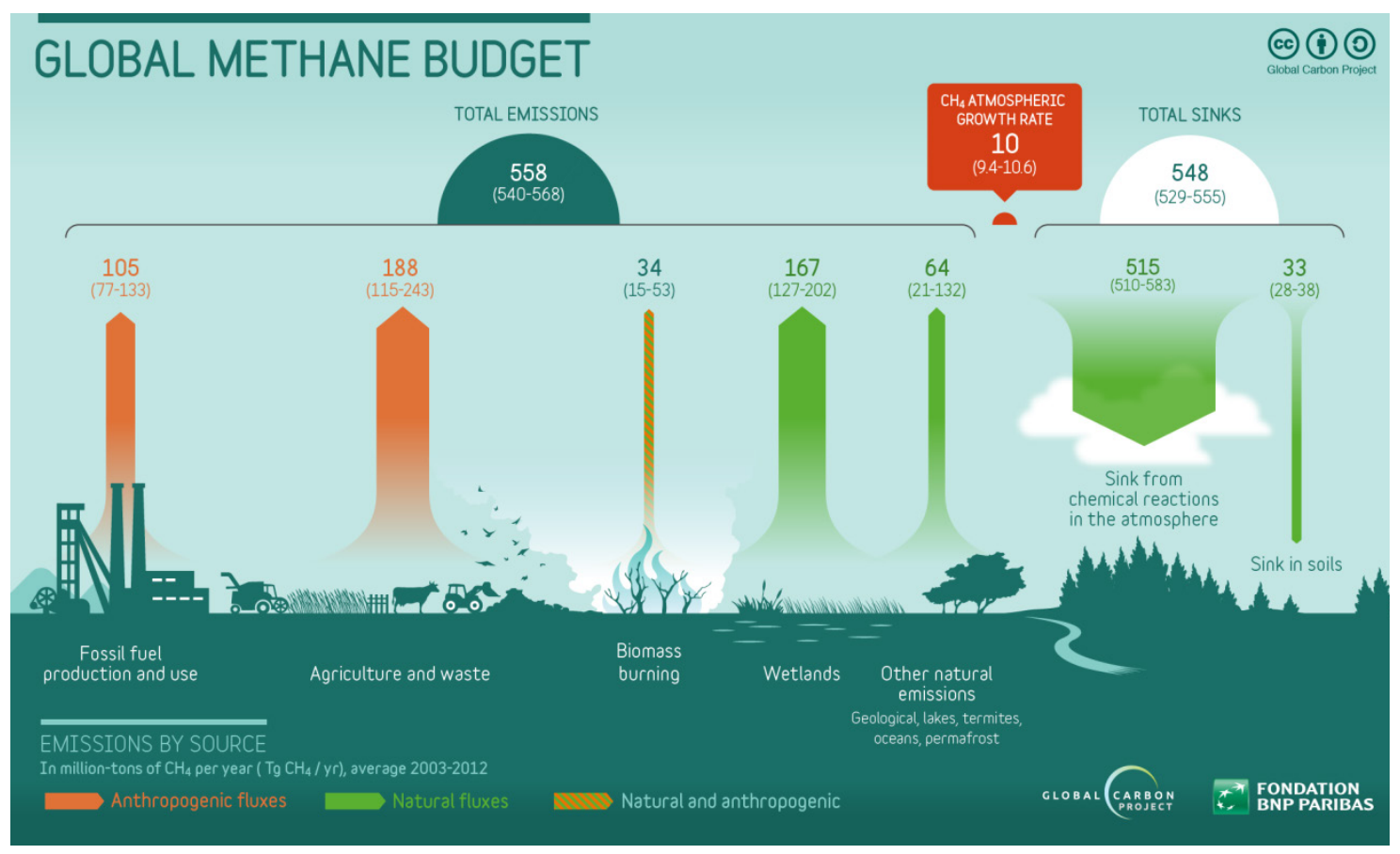

Fig. 2. Global methane budget

Listed above factors should be regulated by farmers themselves, include preventive measures possible to address them.

The main problem of the interaction of agriculture with the environment and other sectors are presented in Table 1.

Table 1

Environmental problems of agriculture

\section{The environmental impact of agriculture}

On land resources:

- development of erosion

- soil compaction due to the impact of heavy machinery

- contamination with harmful chemicals

- overgrazing of animals

On water resources:

- contamination with pesticides and mineral fertilizers

- contamination by livestock

- abstraction of water for irrigation

On the air:

- pollution from livestock farms
External impacts on agriculture

Alienation of agricultural land:

- mining of oil and gas

- construction of hydroelectric power station

- coal mining

- mining of metals

- urbanization

- development of transport network

Pollution and degradation of agricultural land:

- emissions from industry and transport

- nuclear pollution

Pollution of water resources used in agriculture:

- effluents from industry

- sewage of housing and communal services

It shows examples of negative externalities, environmental damage as a result of agricultural activities, and changes in the agricultural sector as a result of external influences [22]. 


\section{Conclusions}

As the result of researches:

1. The environmental risk refers to the probability of the adverse environmental effects of any changes of natural objects and factors. Environmental risks in agriculture are the probability of negative impact on the environment of industrial and technological factors and inaction of business entities.

2. Environmental risks in agriculture may be classified as follows:

1) dependent from business entities (internal) - subjective nature;

2) independent from business entities (external) - objective nature.

A characteristic feature of risks subjective nature is the ability to neutralize the occurrence of environmental problems to a minimum. These primarily include: in crop - entering in pesticides (chemicals) and fertilizers excess; in livestock - wastes of animals and birds.

Common disorders that cause agricultural activities include: contamination of surface waters (rivers, lakes, seas) and degradation of aquatic ecosystems with eutrophication; groundwater contamination; deforestation and degradation of forest ecosystems (deforestation); violation of water treatment over large areas (with drainage or irrigation); desertification as a result of breach of complex structures, soils and vegetation; destruction of natural habitats of many species of living organisms and the consequent extinction and disappearance of rare species.

3. We constructed the following table (Table 2). These tables show the impact of agricultural enterprises (crop and livestock) on the environment and possible interpretation of environmental risks and losses (on the main natural resources - water, land and air).

\section{Table 2}

Assessment of the level of environmental risk and damage in agriculture

\begin{tabular}{|c|c|c|c|c|c|c|c|}
\hline \multirow{3}{*}{ Type of risk } & \multirow{3}{*}{ Risk scale } & \multicolumn{6}{|c|}{ Environmental damage by type of resource } \\
\hline & & \multicolumn{3}{|c|}{ crop industry } & \multicolumn{3}{|c|}{ livestock } \\
\hline & & water & land & air & water & land & air \\
\hline low & $0,00-0,10$ & & & & & & \\
\hline moderate & $0,11-0,25$ & & & & & & \\
\hline average & $0,26-0,50$ & & & & & & \\
\hline high & $0,51-0,75$ & & & & & & \\
\hline catastrophic & $0,76-1,00$ & & & & & & \\
\hline
\end{tabular}

Low risk indicates that the company has little impact on the ecological situation in the territory of its operation. The situation is typical for companies that use organic production. No use of antibiotics, growth stimulants and other preparations in animal husbandry.

Moderate risk indicates the growing impact of farmers on the environment, but within the permissible environmental legislation. The situation is typical for companies using technology as no-till, and organic production. The use of chemicals in animal husbandry and other preparations is situational, as appropriate.

The average value of risk is characterized by the emergence of environmental issues related to individual areas of the enterprise. The company uses an intensive type of production with a gradual transition to the technology mini-till. It uses chemical and other preparations in animal husbandry at the level of allowable without further negative impact on human health.

At the high level of risk, there is not only environmental degradation in the area of the enterprise and the possible negative impact in the current and medium term for the present generation. Enterprises do not follow a legal framework for the environment, science-based system of crop rotation, norms of mineral fertilizers and pesticides, etc. They use chemical plant protection and animal growth stimulants to minimize losses (e. g. epizooty).

Catastrophic risk indicates the activity of the company as a "criminal" in relation to the environment and population in the area of operation. Enterprise violates legislation on the environment, do 
not use crop rotation, use fertilizers and pesticides in a much larger proportion than necessary, causing damage to agrobiocenoses, pollutes water resources (surface and underground). In the production process they use traditional technologies of growing crops, characterized by high energy and lots of air pollutants. In animal husbandry high levels of intensification of production processes combining all sorts of chemical, biological and other preparations to prevent and minimize losses (outbreaks of infectious epizooty diseases) . Damage inflicted by entrepreneurs is extremely high, can lead to environmental disaster. Produced products include high norms of nitrates, antibiotics, hormones, growth stimulants and other chemicals that have a negative impact on human health until death.

Thus, agribusiness philosophy should be based on long-term use of natural resources, minimize the use of chemicals that could harm the environment and humanity.

\section{References}

[1] Inzhinova, L. A. (2008). Sovremennyie tehnologii upravleniya selskohozyaystvennyimi i ekonomiko-ekologicheskimi riskami. Moscow: RUDN, 207.

[2] Fedulova, I., Eds., Hutkevych, S. O., Hryhorovoi, Z. V., Androsiuk, Z. V. (2013). Vplyv silskoho hospodarstva na ekolohiiu. Informatsiina kultura v suchasnomu sviti: materialy naukovoho seminaru. Kiev: NTUU KPI, 2, 24-28.

[3] Yaraya, T. (2014). Klassifikatsiya selskohozyaystvennyih riskov i sposobyi ih snizheniya. Nauchnyiy periodicheskiy elektronnyiy retsenziruemyiy zhurnal "SCI-ARTICLE.RU", 5. Available at: http:// sci-article.ru/stat.php?i=1390338527

[4] Sosenko, O. (2016). Riatuvaty i zakhyshchaty: yak upravliaty ahroryzykamy. Available at: http:// agravery.com/uk/posts/show/ratuvati-j-zahisati-ak-upravlati-agrorizikami

[5] Gorelov, A. A. (2001). Ekologiya: uchebnoe posobie dlya vuzov. Moscow: Yurayt'.

[6] Baranyuk, I. (2015). Ekologicheskaya politika. Problemyi ekologii. Gosudarstvennaya ekologicheskaya politika. Available at: https://www.syl.ru/article/171125/new_ekologicheskaya-politika-problemyi-ekologii-gosudarstvennaya-ekologicheskaya-politika

[7] Food and Agricultural Organisation of the United Nations (2017). Available at: http://www.fao.org

[8] New data on Greenhouse Gas emissions Intensities (2014). Available at: http://www.fao.org/economic/ess/environment/ghgintensities/en/

[9] Dobrovolskyi, V. V. (2014). Ekolohichni znannia. Kiev: Profesional, 299.

[10] Pro okhoronu navkolyshnoho pryrodnoho seredovyshcha: Zakon Ukrainy vid 25.06.1991 № 1264-XII. Available at: http://zakon0.rada.gov.ua/laws/show/1264-12

[11] Krotkov, F. G. (1975). Zagryaznenie okruzhayuschey sredyi i problemyi gigienyi. Priroda, 4, 64.

[12] Selskoe hozyaystvo. Available at: http://studopedia.ru/view_ekonomika.php?id=81

[13] Ekologicheskie aspektyi selskogo hozyaystva. Available at: http://b-energy.ru/biblioteka/ekologiya-i-cheloveki/289-ekologicheskie-aspekty-selskogo-hozyaistva.html

[14] Mahnach, V. Ugroza ekosisteme: problemyi selskogo hozyaystva Belarusi. Available at: http:// greenbelarus.info/articles/28-06-2016/ugroza-ekosisteme-problemy-selskogo-hozyaystva-belarusi

[15] Sonko, S. P. Ekolohichni problemy suchasnoho silskoho hospodarstva ta shliakhy yikh vyrishennia. Available at: http://www.seredniy-klas.org/load/sonko_s_p_ekologichni_problemi_suchasnogo_silskogo_ gospodarstva_ta_shljakhi_jikh_virishennja/1-1-0-2530

[16] Vliyanie pestitsidov na okruzhayuschuyu sredu. Available at: http://agroflora.ru/vliyanie-pesticidov-na-okruzhayushhuyu-sredu/

[17] Yadohimikatyi (pestitsidyi). Available at: https://znaytovar.ru/s/yadoximikaty-pesticidy.html

[18] Nitratyi i nitrityi. Vliyanie na organizm cheloveka. Available at: https://prodobavki.com/modules. php?name $=$ articles\&article_id $=96$

[19] Global Methane Budget 2016. Available at: http://www.globalcarbonproject.org/methanebudget/16/files/GCP_MethaneBudget_2016.pdf

[20] Context. Highlights. Global Methane Budget. Available at: http://www.globalcarbonproject.org/ methanebudget/16/hl-compact.htm

[21] Global Budget. Highlights. Global Methane Budget. Available at: http://www.globalcarbonproject. org/methanebudget/16/hl-compact.htm

[22] Bobyilev, S. N., Hodzhaev, A. Sh. (2003). Ekonomika prirodopolzovaniya Uchebnik. Moscow, 567. 